\title{
Core Factors Governing Manufacturing Procedures and Systems
}

\author{
Duck Weon Lee • Ho Sun Lim* - Woo Sub Shim ${ }^{\dagger}$ \\ Dept. Textile Engineering, Chemistry \& Science, North Carolina State University \\ *Dept. Textile Technology Management, North Carolina State University
}

Received September 1, 2009; Revised (November 16, 2009; December 11, 2009); Accepted December 30, 2009

\author{
의류 생산 시스템을 지배하는 핵심 요소들에 대한 고찰 \\ 이덕원 · 임호선* · 심우섭 ${ }^{\dagger}$ \\ Dept. Textile Engineering, Chemistry \& Science, North Carolina State University \\ *Dept. Textile Technology Management, North Carolina State University \\ 접수일(2009년 9월 1일), 수정일(1차 : 2009년 11월 16일, 완료일 : 2009년 12월 11일), 게재확정일(2009년 12월 30일)
}

\begin{abstract}
This paper reviews four factors involved in apparel and textile manufacturing procedures under international economic fluctuation. This work will be helpful to evaluate the efficiency of global manufacturing systems. Production costs including direct costs related to material and labor costs, and indirect costs associated with manufacturing running ones are significantly correlated to diverse visible and invisible elements such as infrastructure and the labor skills of foreign manufacturing areas, which might create an apparent difference in production costs. Manufacturers can consider how to improve the efficiency of manufacturing systems through a review of the co-relationship between manufacturing procedures and four factors such as manufacturing systems, production outsourcing types, manufacturing locations, and production costs in detail. In addition, the four factors are the core parameters of determining or contributing to the efficiency of a production schedule that is ultimately associated with the supply chain management (SCM) to efficiently conduct Quick Response (QR).
\end{abstract}

Key words: Supply chain management, Quick response system, Manufacturing system, Sourcing price; 공급사슬관리, 신속 대응 시스템, 생산 시스템, 소싱 가격

\section{Introduction}

Many studies have examined the factors that influence the improvement of the apparel and textile manufacturing systems and procedures under the international apparel and textile trade environments. Anderson et al. (1994) mentioned that the main purpose of the manufacturing procedure is to achieve lower total costs and improve the flexibility to respond

Corresponding author

E-mail: jacob0720@gmail.com appropriately to consumers. This paper deals with the external and internal environmental factors such as international economic situations, manufacturing types, location, principles of outsourcing approach methods, and production costs in detail. These factors might influence the optimal flow of the products from manufacturers to consumers through a supply chain. The reason why the optimal flow of the products is important is that it is able to quickly and efficiently respond to the demands of consumers through efficient supply chains of the manufacturing systems 
in the market. Current consumer demands quickly change because they are easily affected by external environments such as mass media including entertainers and magazines. Perry (2000) mentioned that consumers were at the center of the environmental factors and their consumption trends have consistently changed. Barutcu (2007) explained that the demands of consumers mainly pursued lower price, higher quality, and faster delivery. According to the study by Senanayake (2004), the trends of customers have consistently changed from mass production (MP) to mass customization (MC). Senanayake compared the efficiency MC to the divergent apparel assembly systems, production costs, and information technology systems supporting the global production line with those of MP. Senanayake (2004) made an effort to demonstrate the change of the propensity through a comparison and analysis of these factors. $<$ Fig. 1> explains a schematic diagram of this research. According to this schematic plan, this paper demonstrates how those factors influence the efficiency of the manufacturing system in the international apparel and textile supply chain.

This paper selects four factors such as 'physical analysis of manufacturing systems', 'production outsourcing approach', 'distinctive features of manufacturing locations', and 'production costs' related to international economic environments because these factors contribute to the formation of efficient manufacturing systems and procedures that respond to the demands of consumers in the textile and apparel business. The four factors studied in detail in this paper will be helpful for manufacturers to create an efficient supply chain for the manufacturing system.

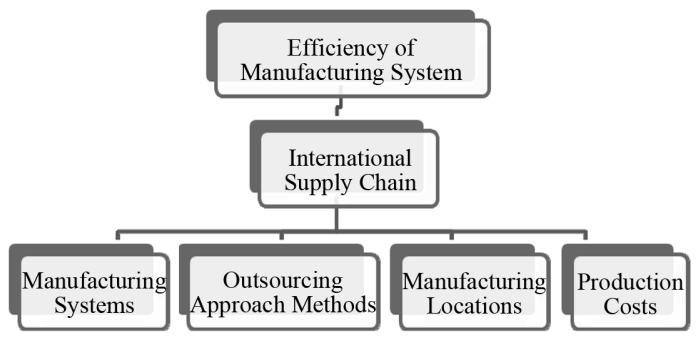

Fig. 1. Core factors affecting efficiency of manufacturing system.

\section{International Apparel and Textile Economy}

Bair (2005) mentioned that in developing countries, the apparel and textile industry was a kind of step-stone approach to an industrialized country because they were able to attract investments from advanced foreign companies that wanted to take advantage of cheap labor costs. Dickerson (1995) explained that developing countries could also learn management from how their industry grows from the advanced companies having advanced management skills. For instance, several companies in the U.S. and France can provide design, marketing, and market information, while the companies in undeveloped and developing countries such as China and Vietnam are able to support raw materials and the profusion of labor resources for producing various apparel products such as toys, clothes, and shoes with low production costs. Especially, the manufacturing conditions of China deemed 'the world factory' has sufficed the apparel and textile business. Gereffi (1999) explained that there was a significant change of the world textile and apparel industry because of Asia, which meant that the sequential challenge of Japan, Newly Industrialized Countries (NICs), and China were distinguished with low labor costs and manufacturing handling skills in the apparel and textile market of the U.S. and the EU. With these challenges, undeveloped and developing countries have recognized that the textile and apparel industries were suitable for the economic development of the labor market and advanced technology. The challenges have been consistently modified against some international agreements such as the Multi Fiber Agreement (MFA) 1, 2, and 3 that intended to protect the uncompetitive textile and apparel industry of some advanced countries.

Morrison (2008) discussed the economic relationships between the U.S. and China. According to '2008 US-China Business Council', China was the biggest exporter to the U.S. and imported a total of \$337.8 billion from China in 2008 (Table 1). <Table 1> shows the top five U.S. imports including computer equipment, miscellaneous manufactured articles, communications equipment, apparel, and audio equipment 
Table 1. Top five U.S. imports from China: 1999-2008 (unit: $\$$ in billions and $\%$ change)

\begin{tabular}{c|r|r|r|r|r|r|r|r|r|r}
\hline \hline & 1999 & 2000 & 2001 & 2002 & 2003 & 2004 & 2005 & 2006 & 2007 & 2008 \\
\hline US Exports & 13.1 & 16.3 & 19.2 & 22.1 & 28.4 & 34.7 & 41.8 & 55.2 & 65.2 & 71.5 \\
\hline$\%$ change & -8 & 24.4 & 18.3 & 15.1 & 28.5 & 22.2 & 20.6 & 32.1 & 18.1 & 9.5 \\
\hline US Imports & 81.8 & 100 & 102.3 & 125.2 & 152.4 & 196.7 & 243.5 & 287.8 & 321.5 & 337.8 \\
\hline$\%$ change & 14.9 & 22.3 & 2.2 & 22.4 & 21.7 & 29.1 & 23.8 & 18.2 & 11.7 & 5.1 \\
\hline Total & 94.9 & 116.3 & 121.5 & 147.3 & 180.8 & 231.4 & 285.3 & 343 & 386.7 & 409.2 \\
\hline$\%$ change & 11 & 22.3 & 21.4 & 21.2 & 22.8 & 28 & 23.3 & 20.2 & 12.7 & 5.8 \\
\hline US Balanoe & -68.7 & -83.7 & -83 & -103.1 & -124 & -162 & -201.6 & -232.5 & -256.3 & -266.3 \\
\hline
\end{tabular}

US exports reported on FOB bssis, imports on a general customs value, CIF basis Retrieved from http://www.uschina.org/statistics/tradetable.html

from China. Phillips (2007) explained that China has expanded in the global apparel and textile market as well it is the fourth largest trading country in the world. Latin America and the Caribbean have also grown as major manufacturers for the apparel and textile products. Abernathy et al. (2004) described that Mexico, Latin America, and the Caribbean apparel suppliers have an advantage as they can offer apparel and textile products to U.S. retailers in less time than other countries due to the close location. Hurreeram and Little (2004) reviewed several international agreements such as the multi fiber arrangement (MFA) specifying the application of quotas and tariffs on imports. The focused on the Africa Growth and Opportunity Act (AGOA) which is a different style of the agreement because the U.S. Congress has allowed the apparel and textile products which are manufactured in sub-Saharan African countries (e.g., Mauritius, Lesotho, Madagascar) to be exempted for duties and quotas in 2000. Even though there are many beneficial treatments such as quota free and non-tariffs for developing sub-Saharan African countries, the volume of their apparel exports is only about $2.3 \%$ of 2001 because of a shortage of basic investments and poor infrastructure. Therefore, Korean and Taiwanese manufacturers produce a part of the orders to take advantage of this agreement to avoid the tariffs and quotas in Africa. In addition, many advanced and developing countries have made complicated international trade relationships according to industrial features such as the level of the economy, the flexibility of the labor market, and labor laws. For exam- ple, Shen and Dickson (2002) have mentioned that China and the U.S. have a close relationship with each other. The U.S retailers such as Wal-Mart and JC Penny, and Chinese manufacturers have attracted U.S. consumers looking for quality apparel products at relatively cheap prices, while the U.S. apparel manufacturers have been losing their competitiveness. Chinese manufacturers have earned great profits due to the foreign exchange rate. According to Morrison (2008), the value of Chinese exports is about 6.5 billion. In the case of Europe, Begg and Pickles (2003) have investigated that several huge companies in France and England took advantage of cheap labor costs and the proximity of the countries of East-Central Europe (ECE), especially ECE6 (Bulgaria, Czech Republic, Hungary, Poland, Romania, and Slovakia). Many Western European buyers profit from low Eastern European production costs.

According to the study by Dixon and Tang (2002), many major companies troubled with increased production costs look for a place where they can produce products with low labor costs. Since it is not easy to directly handle the manufacturing systems, they make a subcontract with local manufacturing companies in the developing countries. Graziani (2001) mentioned that the relocation and subcontract strategy of the manufacturing systems might be conducted as value-added factors because the local owners who run the system were able to actively respond to the change in the external environments such as labor costs and material costs. For instance, the Outward Processing Trade (OPT) policy is beneficial regard- 
ing an additional quantitative quota that is suitable for manufacturers that want to take advantage of the subcontract production system outside of the European Community (EC). In addition, Graziani has indicated several conditions that were suitable for processing decentralized production:

- A product having low fashion content

- Standardization

- Sharing assembly significantly affects the production costs

Kilduff (2005) noticed that export trade system of the U.S apparel product had a unique feature in that about $80 \%$ of the apparel product value was exported to Mexico and CBI (Caribbean Basin Initiative). The reason was that U.S companies were able to take advantage of $807 / 807 \mathrm{a}$, production sharing tariff provision as they produced the products in these areas. Many local manufacturing companies as a production sector in the supply chain also competed with local ones to get production orders from major U.S companies in the apparel market. In addition, Gereffi (2000) mentioned that Latin America and the Caribbean region had consistently increased exports when Asian countries went through a financial crisis. The financial crisis allowed apparel exports from Mexico and the Caribbean Basin to increase and generate many new job positions along with improved exports earnings. Gereffi (2000) and Sellnow (2001) mentioned three international business sectors that consist of a supply chain for the manufacturing systems lead market and policy of the U.S. apparel industry. The first type is retailers. They have dealt with imported apparel products that represent up to $48 \%$ of total imports of the top 100 U.S apparel importers in 1993 and have extended their market influence. The second firm type is marketers such as Liz Claiborne, Donna Karan, Ralph Lauren, and Nike that conduct design and marketing with the foreign and domestic sectors; they do not have manufacturing systems. The last is branded apparel manufacturers. They consider the entire situation and take advantage of reciprocal trade agreements such as 807 and OPT programs.

\section{Core Factors}

\section{Physical Analysis of Manufacturing Systems}

Lin and Moor (2002) defined a manufacturing strategy as a means of the manufacturing company that desires to take an optimal position to win competition with other companies under the changing business environments. Abernathy and Dunlop (1995) mentioned that the U.S. apparel industry tried to accommodate rapidly changing business environments by controlling international market performances and advanced manufacturing technology such as automatic air and light sewing machines, and laser and ultrasonic cutter in the manufacturing system. Meredith and McTravish (1992) have proposed that distinguished arrangement and unique scheduling of the manufacturing system can be an important factor that is able to respond to high product variety and complexity regarding consumer demands. In addition, a well shaped arrangement of the manufacturing system and its appendages such as the sewing machine and their operators should be always ready for application to new marketing strategies. It is important to understand the distribution of production workers who actually run the production in a manufacturing system of the apparel industry because the distribution is directly related to production costs and lead-time. Stylios (1996) has studied intelligent manufacturing systems such as fabric measurement system, sew-ability prediction system, and intelligent sewing machines. Stylios (1996) has focused on the relationship of sewing, fabric, and human resources because the sewing process normally depends on the regulation of the human skill and experience. Besides, it is directly associated with labor costs and product quality. The sewing machine has three processes: Controlling the thread tensions, controlling the feeding foot pressure with an air actuator, and control of the feeding differential and stitch length. Senanayake (2004) has proposed that the efficiency of the sewing parts such as sewing machine speed, attachments, and workplace layout might be a critical approach to reduce the labor costs and improve the productivity of products in manufacturing systems. In addition, he investi- 
gated various features of the apparel assembly systems such as a straight line system, straight bundle system, progressive bundle system, unit production system, and modular manufacturing system. These assembly systems have the following features.

- Straight Line system: It is able to quickly process product production. The unit of the production is a single garment that passes through a line of the operation using conveyors or chutes. The layout must be carefully planned to create efficiency in the production (Fig. 2).

- Straight Bundle system: The unit of the production is a bundle of cut garment parts. The bundle size is determined according to the pile and weight of the fabric. An operator opens, carries, and processes the bundle using a rail or bin (Fig. 3).

- Progressive Bundle system: A large work-in-progress level is required. Bundles of the cut parts are delivered to the sewing room using a rolling truck and performed by operators according to a work schedule. The progression of the bundle unit is processed along the product flow in accor-

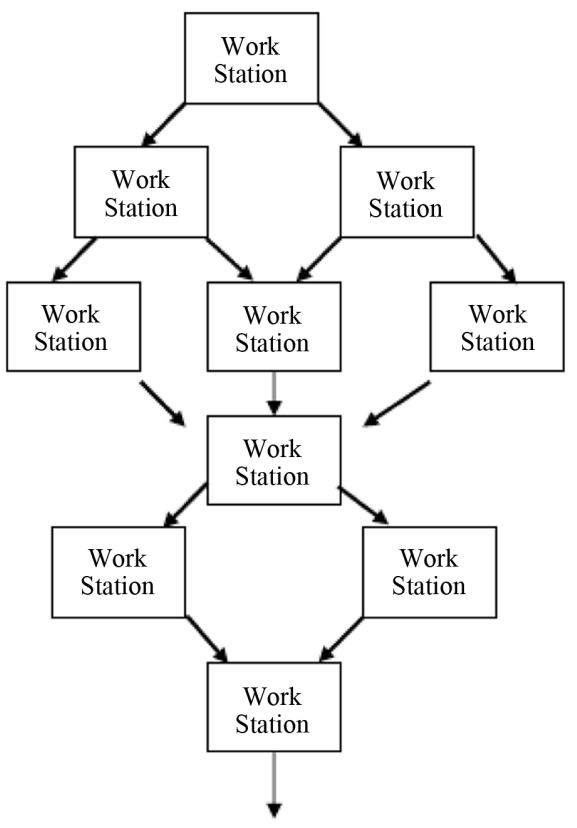

Fig. 2. Straight line system.

From Senanayake, M. (2004). Mixed mass production and mass customization: Best practices for apparel. p. 310. dance with the operation flow (Fig. 4).

- Unit Production system: Operator productivity can be improved and direct labor excess can be reduced. The UPS is a type of line layout system and is manipulated by a central computer system. All parts of the single garment are conveyed and controlled by an electrical hanging carrier (Fig. 5).

- Modular production system: It is able to quickly process product production and the system needs minimal WIP inventory. Since the system consists of the small group, teamwork is important. As this is a hand-off system, each operator completes the work and then passes a single garment or a small bundle to the next operator (Fig. 6).

Lin and Moor (2002) mentioned that the most common size of the apparel assembly systems consisted of 100-249 sewing machines and less 100 employees, reported by 29 plants in 1982. Lin focused on efficient production systems such as a bundle system, a progressive bundle system (PBS) that processed a specified sewing work by individual sewing machine based on standard allocated minutes (SAM), and a modular production system (MPS) based on multiskilled workers in the team. The goal of these systems was to reduce production lead-time and improve production efficiency because the efficiency of these

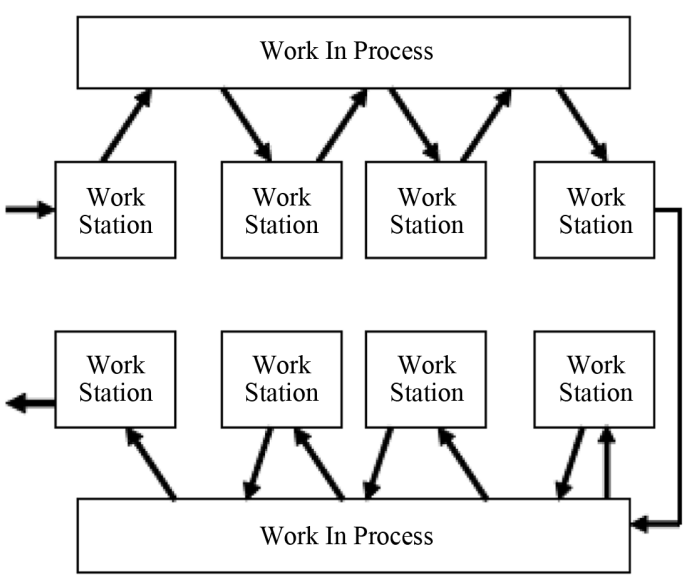

Fig. 3. Straight bundle system.

From Senanayake, M. (2004). Mixed mass production and mass customization: Best practices for apparel. p. 310. 


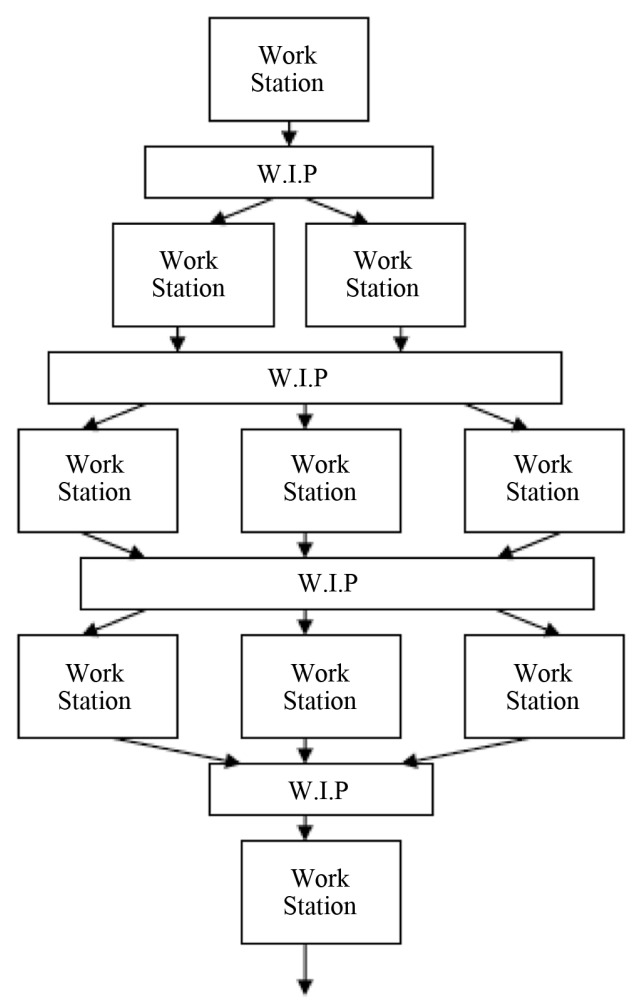

Fig. 4. Progressive bundle system.

From Senanayake, M. (2004). Mixed mass production and mass customization: Best practices for apparel. p. 311.

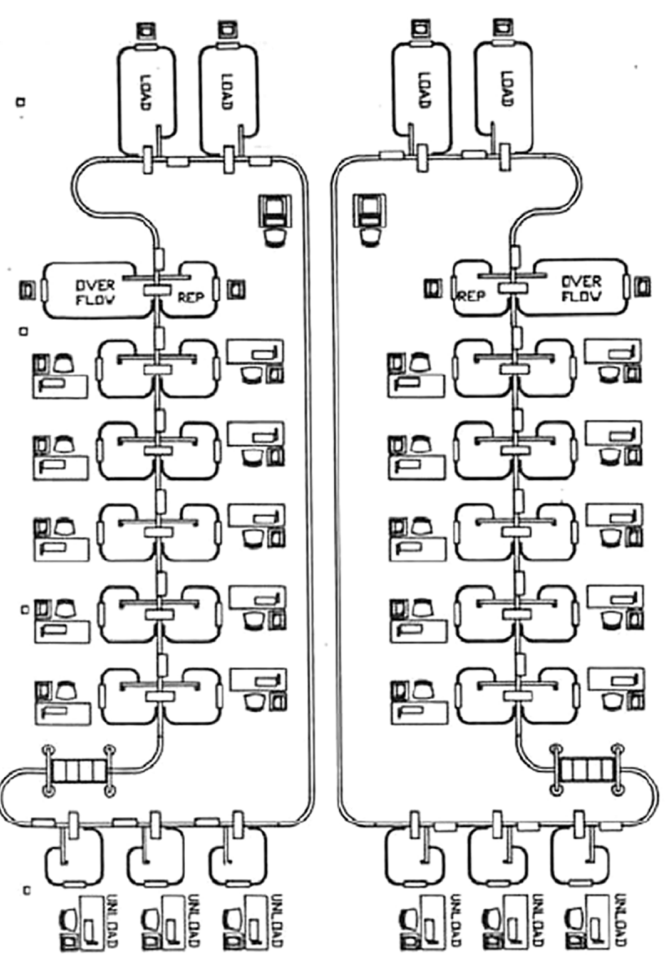

Fig. 5. Unit production system.

From Senanayake, M. (2004). Mixed mass production and mass customization: Best practices for apparel. p. 314.

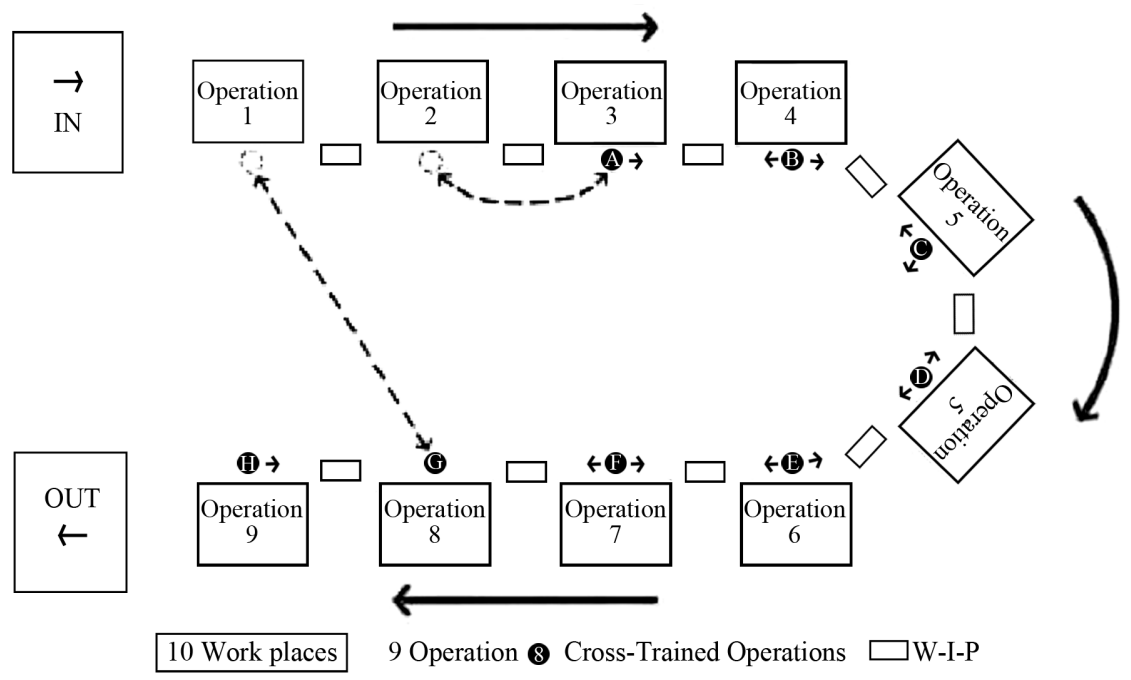

Fig. 6. A schematic of modular production system.

From Senanayake, M. (2004). Mixed mass production and mass customization: Best practices for apparel. p. 314. 
systems was related to production costs and profits. Cameron (1992) explained the attribution for modular manufacturing compared to other systems in detail because this production system is not fixed and is too flexible (Fig. 7).

According to the investigation by Dunlop and Weil (2000), a typical men's dress shirt need 18 minutes of direct labor, a pair of trousers 24 minutes, knit pants 3 minutes, and a T-shirt 1.5 minutes under the PBS. In addition, they compared and analyzed the PBS system and MPS from the point of view of the apparel industry. PBS (a traditional system) focused on how to reduce the production lead-time and maximize the productivity of a system. MPS is a flexible system that considered teamwork and individual personality based on high skills. In addition, Tang et al. (1994) also explained that the traditional bundle system should process a high level of work-in-process within limited time, which meant that only 10-20 minutes of direct labor contents were needed to assemble a garment.

Yen (2002) explained that the processes of supply chain of the textile industry involve product design and development, material sourcing and product manufacturing, product distribution, and retailing of product. In addition, $60 \%$ of prototype should be processed within 45 days of the lead-time, and the lead-

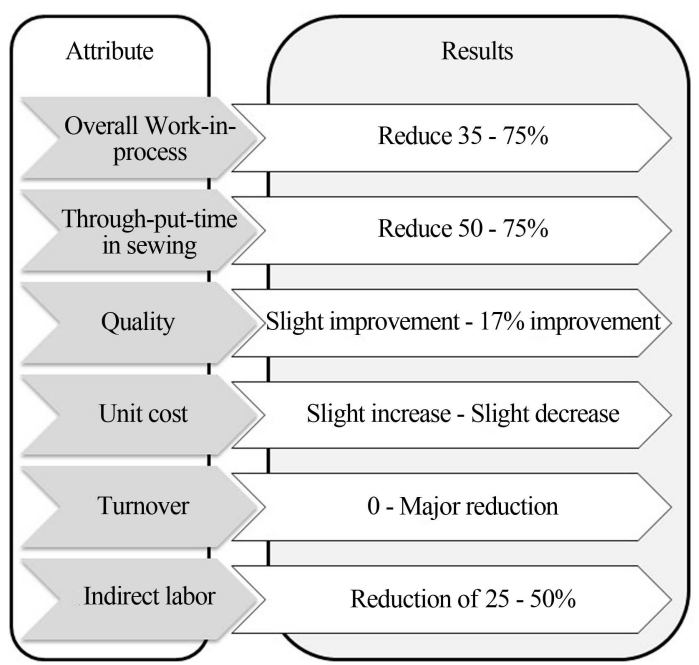

Fig. 7. Attribution and results of modular manufacturing. time is 30 days with 8 inventory turns annually from manufacturer to distributor. For a distributor and retailer, $90 \%$ of the order should be completed within 24 hours; the total lead-time of the supply chain needs at least 76 days. However, this lead-time is not stable and can change according to the style and amount of the apparel products. There are many additional factors such as the season and the production skills of the subcontractors that influence production lead-time. To have an effective manufacturing procedure, the apparel companies should make a decision on which system is suitable for business between the lean supply system and agile supply system. Normally, the lean supply and agile supply has different styles and features according to the type of products.

Mason-Jones et al. (2000) have made a table to compare the lean supply with an agile supply. <Table $2>$ compares the lean supply with the agile supply.

Chin (2004) explained several strategic factors that influence efficient supply chain management (SCM) among several sectors such as manufacturers, distributors, retailers, and customers: building customer-supplier relationships, employing information and communication technology, re-engineering material flow, changing corporate culture, and identifying performance measures. It is necessary to create and use efficient information technology to assist the strategic factors from among the sectors in the SCM. Adler (2004) explains that the technological approach of the textile and apparel industry is different. The textile industry focuses on a technological paradigm that improves manufacturing systems in order to compensate for high labor costs and the apparel industry is concentrated on implementing informa-

Table 2. Comparison of lean supply and agile supply

\begin{tabular}{c|l|l}
\hline \hline Distinguishing attributes & Lean supply & Agile supply \\
\hline Typical product & Commodities & Fashion goods \\
\hline Market placed & Stable & Unstable \\
\hline Product life cycle & Long & Short \\
\hline Product variety & Low & High \\
\hline Mfg task & Low cost & Delivery speed \\
\hline
\end{tabular}

From Mason-Jones, R., Nayor, B., \& Towill, D. R. (2000). Engineering the lean and agile supply chain. p. 57. 
tion and communication to satisfy consumer demands in the market. There are many types of manufacturing systems and information technology to improve the flow of the products and information along the supply chain network in the international manufacturing system. Abernathy et al. (1999) investigated that several qualified systems such as bar codes, electronic data interchange (EDI), a modern distribution center, and standards rules were essential factors to promote the efficiency of relationships between the retailing and manufacturing systems. In addition, they have explained that the relationship plays an important role to determine the product inventory level that is critical for a manufacturer to deal with sales orders and delivering the products to the retailers on time. He asserted that a Point of Sales (POS) system might be used to efficiently maintain the relationships among the sectors of the supply network. However, one of the most important things is that the retailers and manufacturers should share ordering information and have similar levels of information technology to stimulate an efficient retailing and manufacturing system. Caputo (2005) explained that the manufacturing system that actively uses information technology (e.g., electronic data interchange, point of sale scanners, bar coding, and logistic improvement) is able to cut production lead-time and product costs. Richardson (1996) emphasized that fashionable products claim a closer relationship between retailer and manufacturer in the taking advantage of the POS systems because retailers wish to share risks in dynamic business environments with the manufacturers. Forza (1997) mentioned what the roles of information technology are among chain sectors: producer order, exchange of administrative documents (invoices and delivery notes), and exchange of commercial lists (material, material availability). Forza (1997) said that manufacturers and retailers should consider how to deal with annual costs related to inventory carrying, shortage, and excess supply costs after it produces products. Even though the manufacturers have difficulty in getting information regarding sales orders in advance, it is necessary to make a manufacturing plan and schedule to lower production costs. Fisher (1996) has said that total amount of these costs related to forecast error is estimated at about $\$ 25$ billion and $25 \%$ of the retail sales, which means that it was important to look at the minimum level of sales orders through stochastic information. Textile and apparel manufacturers have made an effort to have an expectable level of inventory stock and run the manufacturing systems under a completed production plan. In addition, in the paper 'The strategic integration of agile and lean supply' and 'Build-to-order \& mass customization,' Stratton and Warburton (2003) and Anderson (2004) indicated that imprecise sales forecast of consumer demands might cause a high level of surplus or a shortage of the product. High forecasts cause over-inventory and low forecasts produce lost sales and disappointed customers. For example, Sports Obermeyer, a skiwear company, had difficult in responding to the volatile demand and short life cycles because of inaccurate consumer demands. Therefore, Stratton and Warburton (2003) emphasized that the amount of products should be produced based on one accurate investigation regarding protective inventory and capacity. According to Anderson, another important factor in the manufacturing procedure is that a manufacturer must follow and standardize the industry because it could result in cost reduction, better quality, increased flexibility, and a faster responsiveness. In conclusion, even though there are several manufacturing assembly systems, the manufacturer should identify which type is suitable for the supply chain because the appropriate choice might have optimum productivity for their manufacturing system.

\section{Production Outsourcing Approach}

Barutcu (2007) h proposed that the textile and apparel companies setting up internet-based SCM are able to quickly respond to consumer demands as well as improve production sourcing ability with local manufacturers. Through the internet information systems, the main retailers or brand marketers can communicate with subcontractors in real time to minimize production costs. Another advantage is that internetbased SCM were flexible under changeable business environments, and the initial and maintenance costs were comparatively cheaper than those of other infor- 
mation systems. Stratton and Warburton (2003) explained that many retailers and companies should focus on offshore supply systems to strengthen their production competitiveness. For example, the Griffin manufacturing company takes advantage of a hybrid delivery system that is mixed with the low supply costs and the fast response capability of the local supplier in the Honduras.

Crestanello and Dalla-Libera (2003) explained that outsourcing places can be different according to the type of product and production planning time. For instance, in the case of outsourcing as a major firm by Italian companies, knitwear can be mainly manufactured in Portugal and Mauritius, and silk garment, T-shirts, and sportswear are produced in China and India. Furthermore, the sourcing price can be influenced by other extraneous factors (e.g., economic condition, political condition, regional difference, buyer/ seller relationship, etc.).

To efficiently conduct appropriate sourcing strategies in the global network, Kim and Rucker (2005) suggested some conditions: lead-time between placing the production order and receiving the order, 'Flexibility considering manufacturing technology and transaction ability of subcontractors', 'Labor costs in the offshore production', and 'Years in business, which means retailing experiences.' Kim and Rucker (2005) explained that these above factors might be considered when companies make a decision if a place is appropriate for sourcing because these factors will influence transaction costs. However, Anderson (2004) mentioned that there are several disadvantages in the production of outsourcing strategy. For instance, it is difficult to handle the quality and standardization of the products, which means that major companies must relocate supervisors to look for the quality and train the subcontractors. In addition, the significant problem is that the subcontractors including maintain quality, hidden costs, training potential rivers, and the slow production speed of the SCM will become a strong player in the market. Anderson proposed that retailers and international agents must consider the over several criteria (e.g., standard parts, modularity, skill talent, company-specific lines, and cooperation) for outsourcing decision. Christerson and Appelbaum
(1995) have also insisted that, although low labor costs are a critical factor affecting determination of the location of apparel production, other factors such as firm size, ethnicity, market strategy, and trade regulations cannot be disregarded. In addition, Stratton and Warburton (2003) also explained several reasons why some companies continue to directly run manufacturing systems in the U.S, even though the production costs are high. This is because of hidden offshore manufacturing costs such as a $40 \%$ turnover, logistic problems, and company expense accounts for travel. In conclusion, it is important to have good relationships with subcontractors to keep the production schedule on time because most manufacturers have an incomplete manufacturing system. In addition, they hedge against the global economic fluctuations and reduce production costs by actively using local labors.

\section{Distinctive Features of Manufacturing Loca- tions}

Bolisani and Scarso (1996) focused on manufacturing locations. They explained that a strategy for the manufacturing locations is important because it is related to outsourcing production, production costs, and production lead-time. The manufacturing location as a core of business strategy should be carefully determined in accordance with the main purpose of the manufacturing procedures or a kind of products. For example, while design should be conducted in advanced countries, cutting and assembly should be conducted in developing countries. Appropriate decentralization or concentration of the manufacturing systems considering the features of the location might be important to make each sector work in an efficient manner. In particular, Gibbson (2003) mentioned that China and Turkey as a production base camp had diverse merits such as proximity, raw materials, and cheap labor costs to produce apparel products in the global apparel market. According to reports of the National Council of Textile Organizations (NCTO), China will take up to about $71 \%$ of the U.S. textile and clothing market by 2006. Graziani (2001) mentioned that the Chinese economy had started to di- 
rectly accept foreign investment at the end of the 1970s. In addition, about $60 \%$ of Chinese clothing exports are made by subcontracts with foreign companies. In addition, the clothing exports of Hong Kong, South Korea, and Taiwan have been routed to the U.S and Canadian markets via the manufacturing systems of China to conduct an assembly operation. According to the World Bank (2000), the first exporter was China (16.2\%), Italy (7.1\%), and the USA (4.4\%) follow as the second and third exporter as a provider of the apparel product. In particular, the textile and apparel industry of China is dramatically growing with other foreign companies. Garwood (2005) mentioned that after the closing of the MFA related to quotas, the textile and apparel industry of China has been curbed by the US and EU because of them competitive power of China. Fang et al. (2004) also indicated that China has diverse strong points such as low material costs and abundant labor. However, foreign investment trends are different in accordance with its provinces' properties, which mean that the product type of the coastal regions such as Beijing, Shanghai, and Guangdong have slowly changed from textile and apparel products to technology products such as mobile and cellar phones. In the reports of Haisma-Kwok (2003), Chinese textile manufacturers (who consist of about 70,000 textile and clothing companies) produced 5.3 million tons of textiles or about one-quarter of the global output in 2002. The Chinese power in the textile and apparel industry is increasing and threatens the global apparel industry market. In addition, the power of China in the textile and apparel industry will increase as the quota restrictions under the MFA are phased out in 2005 (HaismaKwok, 2003). Therefore, Andriamananjara et al. (2004) explained that China would have a special chance to export its products due to the belief that Chinese competitive power such as strong human and material resources would be able to sufficiently overpower the challenges of other countries in the market. In addition, China itself has a huge market for consuming products based on a high economic improvement.

China has sufficient labor power and rich natural sources which are suitable for developing the apparel and textile industry. Another advantage of Turkey is geographical proximity to the European market, which means that Turkey is capable of efficiently responding to consumer needs for the market. Therefore, Turkey is expected to maintain a status of the top exporter for European markets for a long time.

\section{Production Costs}

Production costs can include diverse factors such as delivery costs, labor costs, and material costs. In particular, Anderson (2004) mentioned that the majority of total cost is "overhead," which mainly related to 'fixed costs' in mass customization. However, about $80 \%$ of the revenue is associated with about $80 \%$ of the direct costs regarding material and labor. Uncu (2003) explained that there are several kinds of production costs such as the total cost of the product, cost of quotas, tax rates, and transaction costs. The production costs should reflect the exchange rate among countries in the income statement. The exchange rate acts as the main catalyst in making a profit because exports and imports among countries are transacted in each account in local currencies. For example, according to For example, according to Joshi and Singh (2008), exports related to the textile and clothing of India fell about $13.4 \%$ in 2003/2004 compared with 2002/03 because of decrease of value of rupee. Senanakeya (2004) explained the payment system for workers according to the style of the manufacturing system. In particular, direct labor costs make the decision of the level of cost of goods sold in the sewing part of the manufacturing system. There were several kinds of manufacturing systems such as a straight line system, a straight bundle line system, a progressive bundle system, and a modular manufacturing system. Under these systems, the method of payment has a significant influence on the total production costs.

Many apparel manufacturing systems have made an effort to reduce the production costs (except for labor costs) of other parts such as packing, distribution, and delivery with information technology. For example, Forza (1997) mentioned the advantage of telecommunication such as easier communication that 
responds quickly to shift demands and means that as information technology improved the cooperative transaction among chain sectors that has reduced production costs. Stratton and Warburton (2003) compared manufacturing costs in Griffin (New England), a manufacturing company, and the Honduras regarding a medium-range jogging bra. According to Stratton and Warburton (2003), it was assumed that a reasonable estimate of the total labor costs per hour of both Griffin (New England) and Honduras were \$1.50 and $\$ 0.06$ respectively. In conclusion, since the apparel and textile industry should strongly consider the labor and material costs, many manufacturing systems will move into developing and undeveloped countries such as Indonesia and Honduras that have low labor costs. Manufacturers should prepare a plan on how to efficiently build a manufacturing supply chain with those places together.

\section{Summary}

Just this paper addressed four factors affecting the apparel and textile manufacturing system under the global business environment. Researchers have introduced that the factors such as manufacturing systems, specialized locations, outsourcing approach methods, and production costs are closely associated with the efficiency of the manufacturing system within an international supply chain, even though they did not know the type of the manufacturing system and the best location for the apparel and textile industry. However, it may disturb production efficiency due to the addition of training costs for new employees and increasing delivery costs. Currently, the labor costs in coast areas such as Shangdong, Shanghai, and Tian- jin of China have dramatically increased. Some manufacturing systems are being moved to inland China or East Asia such as Indonesia or Vietnam to take advantage of low labor costs. This paper indirectly ascertains that while the core factors influenced the apparel and textile industry, the peripheral environments around the apparel and textile industry of the subcontract relationships, exchange rates, and geographical proximity also affect them. Additionally, many sectors in the international supply network compete with each other for a long time in the global apparel market according to a change of international treaties such as MFA and OPT. This study suggests that the apparel company needs to deal with the trends in the future apparel market changes for a mass customization and a quick response system. The apparel and textile industries have to build the manufacturing systems and production outsourcing approach that satisfy consumer desires and low labor/product costs to cope with the future market. <Table 3> summarized the implications of four core factors for the textile and apparel manufacturing procedures and systems. Manufacturers need to find out right the manufacturing systems for the supply chain because it will affect the productivity of the entire supply chain. In the production outsourcing approach, it is important to have a good relationship with subcontractors, which improve the productivity of the production and control a hedge against a variety of risks. Manufacturing locations should have some conditions with sufficient labor power, rich natural resources, and a proximity to the markets. In addition, manufacturers need to decide suitable manufacturing locations and production costs in consideration of the manufacturing systems.

Table 3. The implications of four core factors for the textiles and apparel manufactruring procedures and systems

\begin{tabular}{c|c|l}
\hline \hline 1 & Factor & \multicolumn{1}{|c}{ Effect } \\
\hline 2 & Production outsourcing approach & $\begin{array}{l}\text { Diverse roles and efficiency of manufacturing systems ultimately influence on pro- } \\
\text { ductivity of the manufacturing systems } \\
\text { production and handle a hedge against divergent risks }\end{array}$ \\
\hline 3 & Features of manufacturing locations & $\begin{array}{l}\text { To be an efficient manufacturing location, it must have some conditions such as } \\
\text { sufficient labor power, rich natural resources, and proximity }\end{array}$ \\
\hline 4 & Production costs & $\begin{array}{l}\text { Production costs render efficient global rearrangement of the manufacturing sys- } \\
\text { tem as a way of saving the costs }\end{array}$ \\
\hline
\end{tabular}




\section{Limitation and Future Studies}

This study deals with four factors affecting the global manufacturing systems, but fails to provide empirical data regarding each factor with examples. Therefore, future studies need to investigate supporting examples for each factor through case studies. Based on the data, future research will verify why these factors are important.

\section{References}

Abernathy, F. H., \& Dunlop, J. T. (1995). A study of US apparel industry in transition: Brookings papers on economics activity. Macroeconomics, 1, 175-246.

Abernathy, F. H., Dunlop, J. T., Hammond, J. H., \& Weil, D. (1999). Stitch in time: Lean retailing and the transformation of manufacturing-lessons from the apparel and textile industries. New York: Oxford University.

Abernathy, F. H., Dunlop, J. T., Hammond, J. H., \& Weil, D. (2004). Globalization in the apparel and textile industries. In M. Kenney \& R. L. Florida (Eds.), Locating global advantage: Industry dynamics in the international economy (pp. 23-51). CA: Stanford University Press.

Adler, U. (2004). The dominant feature in the economic development of the German textile and clothing industries. Journal of Fashion Marketing and Management, 8(3), 300-319.

Anderson, D. M. (2004). Build-to-order \& mass customization; the ultimate supply chain management and lean manufacturing strategy for low-cost on-demand production without forecasts or inventory. California: CIM Press.

Anderson, J. C., Håkansson, H., \& Johanson, J. (1994). Dyadic business relationships within a business network context. Journal of Marketing, 58(4), 1-15.

Andriamananjara, S., Judith, D., \& Dean, S. (2004, May). Trading apparel: Developing countries in 2005. Paper at the $7^{\text {th }}$ Annual Conference on Global Economic Analysis, Washington, DC.

Bair, J. (2005). Global capitalism and commodity chains: Looking back, going forward. Competition \& Change, 9(2), 153-180.

Barutcu, S. (2007). Customized products: The integrating relationship marketing, agile manufacturing and supply chain management for mass customization. Ege Academic Review, 7(2), 581-601.

Begg, B., \& Pickles, J. (2003). Cutting it: European integration, trade regimes, and the reconfiguration of East-Central European apparel production. Environmental and
Planning, 35, 2191-2207.

Bolisani, E., \& Scarso, E. (1996). International manufacturing strategies: Experience from the clothing industry. International Journal of Operations \& Production Management, 16(11), 71-84.

Cameron, A. B. (1992). Perspective on productivity: How do we maximize productivity? The Third Annual Academic Apparel Research Conference, Atlanta, Georgia.

Caputo, A. C. (2005). Manufacturing re-insourcing in the textile industry. Industrial Management \& Data system, 105(2), 193-207.

Chin, K. S. (2004). A study on supply chain management practices. International Journal of Physical Distribution \& Logistics Management, 34(6), 505-524.

Christerson, B., \& Appelbaum, R. P. (1995). Global and local subcontracting: Space, ethnicity, and the organization of apparel production. World Development, 23(8), 1363-1374.

Crestanello, P., \& Dalla-Libera, P. E. (2003). International delocalization of production: The case of the fashion industry of Vicenza. Economic and social region, 82(2), $1-27$.

Dickerson, K. (1995). Textiles and apparel in the global economy. NJ: Englewood cliffs.

Dixon, G., \& Tang, T. (2002). Asian light fabric: Manufacture and wearer comfort. Manchester: Manchester Metropolitan University Business School Working Paper Series.

Dunlop, J., \& Weil, D. (2000). Diffusion and performance of modular production in the U.S. apparel industry. In C. Ichniowski, D. I. Levine, C. Olson, \& G. Strauss (Eds.), The American workplace: Skills, compensation and employee involvement (pp. 38-61). Cambridge, UK: Cambridge University Press.

Fang, T., Olsson, D., \& Sporrong, J. (2004, September). Sourcing in China: The Swedish experience. Paper at the $20^{\text {th }}$ Annual IMP Conference, Copenhagen.

Fisher, M. (1996). Reducing the cost of demand uncertainty through accurate response to early sales. Operation $R e-$ search, 44(1), 87-99.

Forza, C. (1997). Quick response in the textile-apparel industry and the support of information technology. Integrated Manufacturing System, 8(3), 125-136.

Garwood, S. (2005). Politics at work: Transnational advocacy networks and the global garment industry. Gender and Development, 13(3), 21-33.

Gereffi, G. (1999). International trade and industrial upgrading in the apparel commodity chain. Journal of International Economics, 48, 37-70.

Gereffi, G. (2000). The transformation of the North American apparel industry: Is NAFTA a curse or a blessing? Integration and Trade, 4(11), 47-95.

Gibbson, P. (2003). The African growth and opportunity act 
and the global commodity chain for clothing. World Development, 31(11), 1809-1827.

Graziani, G. (2001). International subcontracting in the textile and clothing industry. In S. W. Arndt \& H. Kierzkowski (Eds.), Fragmentation and New Production Patterns in the World Economy (pp. 209-30). Oxford: Oxford University Press.

Haisma-Kwok, C. (2003, September 26). The countdown to 2005: As U.S. industry quakes, China has its own fears. Women's Wear Daily. Retrieved August 26, 2008, from www.tiburonresearchgroup.com/pdfs/2003_0923_China 2005.pdf

Hurreeram, D. K., \& Little, D. (2004). International apparel trade and developing economies in Africa. International Journal of Clothing Science and Technology, 31, 131-142.

Joshi, R. N., \& Singh, S. P. (2008). Textile \& clothing exports: Trends \& prospects. The Indian Textile Journal. Retrieved December 11, 2009, from http://www. indiantextilejournal.com/articles/FAdetails.asp?id=1546

Kilduff, P. (2005). Patterns of strategic adjustment in the US textile and apparel industries since 1979. Journal of Fashion Marketing and Management, 9(2), 180-194.

Kim, Y., \& Rucker, M. (2005). Production sourcing strategies in the U.S. apparel industry: A modified transaction cost approach. Clothing and Textile Research Journal, 23(1), 1-12.

Lin, S. H., \& Moor, M. A. (2002). Dimensions of apparel manufacturing strategy and production management. International Journal of Clothing Science and Technology, 14(1), 46-60.

Mason-Jones, R., Naylor, B., \& Towill, D. R. (2000). Engineering the lean and agile supply chain. International Journal of Agile Manufacturing Systems, 2(1), 54-61.

Meredith, J. R., \& McTavish, R. (1992). Organized manufacturing for superior market performance. Long Range Planning. 25(6), 63-71.

Morrison, W. M. (2008). CRS report for congress; ChinaU.S. Trade Issues. NJ: Cornell University ILR School.

Perry, M. (2000). Quick response practices and technologies in developing supply chains. International Journal of Physical Distribution \& Logistics Management, 30(7/8), 627-639.

Phillips, N. (2007, January). Consequences of an emerging China: Is development space disappearing for Latin
America and the Caribbean. CIGI Conference, Global Governance and the contours of Domestic Politics in the Americas, Waterloo, ON.

Richardson, J. (1996). Vertical integration and rapid response in fashion apparel. Organization Science, 7(4), 400-412.

Sellnow, T. L. (2001). Establishing the structure of reality for industry: Model and anti-model arguments as advocacy in Nike's crisis communication. Journal of Applied Communication Research, 29(3), 278-295.

Senanayake, M. (2004). Mixed mass production and mass customization: Best practices for apparel. Unpublished doctoral dissertation, North Carolina State University, Raleigh, NC.

Shen, D., \& Dickson, M. (2002). Apparel exports from China to the United States: A marxist perspective. Clothing and Textiles Research Journal, 20(4), 215-226.

Stratton, R., \& Mann, D. (2003). Systematic innovation and the underlying principles behind TRIZ and TOC. Journal of Materials Processing Technology, 9(79), 120126.

Stratton, R., \& Warburton, R. D. H. (2003). The strategic integration of agile and lean supply. International Journal of Production Economics, 85(2), 183-198.

Stylios, G. (1996). The principles of intelligent textile and garment manufacturing systems. Assembly Automation, 16(3), 40-44.

Tang, Z. -B., Hammond, J. H., \& Abemathy, F. H. (1994). Design and scheduling of apparel manufacturing systems with both slow and quick production lines. Processing of the $33^{\text {rd }}$ Conference on Decision and Control, Lake Buena Vista, FL, 1603-1608.

Uncu, S. (2003). Customized international investment decisions: An exploration into the textile and apparel decision-making process. Unpublished doctoral dissertation, North Carolina State University, Raleigh, NC.

US-China Business Council. (2008). US-China trade statistics and China's world trade statistics. US-China Business Council. Retrieved July 25, 2009, from http:// www.uschina.org/statistics/tradetable.html

World Bank. (2000). Entering the 21st Century, World Bank World Development Report 1999/2000. New York: Oxford University Press.

Yen, C. P. (2002). Electronic commerce front-end in apparel supply chain. Computer \& Industrial Engineering, 42(2-4), 471-480. 


\section{요 약}

이 논문은 생산 과정에 영향을 미치는 다양한 요소들 즉, 생산 원가, 생산 장소, 그리고 전반적인 경제 여건에 대해서 고찰하고 있다. 왜냐 하면, 현재 많은 생산 시스템들이 원가 상승의 압박에 의해 생산 시설 의 지역이동이나 정보 통신을 이용한 효율적인 공급사슬관리를 운영하길 원한다. 예를 들어, 중국에서의 노동 생산 원가는 상당히 증가 하고 있기 때문에 그 생산 시설이 서서히 동남아시아로 이동하고 있다. 그 러나 동남아시아의 인프라나 그 지역 노동자의 생산 숙련도가 아직은 미흡하기 때문에 생산 시설을 옮기 기 보다 더욱 효과적인 방법들이 강구되고 있다. 그러므로 이 논문은 그러한 다양한 요소들이 생산 과정 에 미치는 영향을 고찰 함으로써, 우리가 그 요소들을 이해하고 앞으로 어떤 방향으로 생산 시스템을 운 영해 나가야 할지 방향을 제시해 줄 수 있을 거라 판단된다. 